GEOLOGICA BALCANICA, 46 (2), Sofia, Nov. 2017, pp. 57-63.

\title{
The ammonite zones of the Bathonian in Bulgaria
}

\author{
Lubomir Metodiev, Ivo Sapunov
}

Geological Institute, Bulgarian Academy of Sciences, Acad. G. Bonchev Str., Bl. 24, 1113 Sofia, Bulgaria;

e-mail:lubo@geology.bas.bg.

(Accepted in revised form: October 2017)

\begin{abstract}
A scheme of nine ammonite zones for the Bathonian in Bulgaria is described herein. The stratigraphical distribution of the Bathonian ammonites has been revised through new collecting and re-examination of older collections and fields. It has become evident that the criteria for zonal discrimination applied in NW Europe are relevant for Bulgaria to a limited extent, and we cannot compare directly our successions with those from the NW European areas as done in earlier work. Also, many traits of typically Submediterranean dispersal have been found to take a considerable part of the ammonite associations. Therefore, a composite Submediterranean-NW European zonation seems to be applicable to the Bathonian ammonite successions in Bulgaria. The ammonite zonal scale used in previous Bulgarian accounts has been retained, but several changes have been made to attain a more balanced sequence. This scale can be subject to further confirmation and modification, as not enough biostratigraphically well-constrained specimens have yet become available to characterize the ranges and variability of the zones.
\end{abstract}

Metodiev, L., Sapunov, I. 2017. The ammonite zones of the Bathonian in Bulgaria. Geologica Balcanica 46 (2), 57-63.

Keywords: Bathonian, ammonite zones, Bulgaria.

\section{INTRODUCTION}

The marine sediments of the Bathonian in Bulgaria are developed in two main facies: shallower (ooidal-crinoidal-bioclastic limestones and calcareous sandstones) and deeper-marine (mudstone-marlstone deposits). The shallower facies corresponds to the Polaten Formation and has yielded well-preserved ammonites, mostly from the highly condensed stratigraphic intervals in NW Bulgaria (e.g., SacharievaKowatcheva, 1956; Stephanov, 1961, 1966, 1972). The deeper-marine facies refers to the marlstone-limestone successions of the Bov Formation and crops out in West and central North Bulgaria. It is less known regarding the ammonites (e.g., Stephanov, 1963) but, being developed in more expanded ammonite-bearing sequences, it has good potential for biostratigraphical studies. Our attempts over recent years to find new diagnostic ammonite associations in the deeper-marine sediments were partly rewarded as we have identified stable successions in superposition, but also a number of condensation events and gaps. The ammonites from this facies are seldom well-preserved and therefore problematic for the purposes of biostratigraphical classification. Thus, in the Bathonian ammonite record in Bulgaria, there is a serious imbalance. Many ammonites were well studied from taxonomic viewpoint, mainly due to the dedicated research of July Stephanov, but the stratigraphical distribution of the identified taxa still remains unclear. After the death of Stephanov in 1966, the studies of Bulgarian Bathonian ammonites ceased and to date there has been little further contribution. We retain the Bathonian ammonite zonal scale published by Sapunov and Stephanov (1964) and Stephanov $(1966,1972)$, with several changes, both of which can be subject to further confirmation and modification. These alterations are necessary for attaining a more balanced zonal sequence, as compared with that of previous works, which followed the scheme of Arkell's monograph The English Bathonian ammonites. This report includes reduced faunal and reference lists and will be presented in more details elsewhere.

\section{THE BATHONIAN AMMONITES IN BULGARIA}

The Jurassic ammonite faunas of Bulgaria exhibit a marked transition in the Bathonian, from Northwest European to Submediterranean appearance. Accord- 
ingly, the NW European criteria for zonal discrimination, applied for instance in the UK, Germany and Northern France (e.g., Cope et al., 1980; Schlegelmilch, 1985; Mangold et al., 1994), are relevant for that of Bulgaria to a limited extent, and we cannot compare directly our successions with those from the NW European areas as done in earlier work. We propose a Bathonian ammonite scheme, having NW European elements but also including traits of Submediterranean dispersal, which are close to some coeval faunas recorded in Spain, SE France, SW England, Italy and Hungary (e.g., Sandoval, 1983; Page, 1996; Géczy and Galácz, 1998; Mangold et al., 2012) and hence comparable with the Submediterranean zonation proposed by Mangold and Rioult (1997). A number of the European Submediterranean faunas are, however, not known in Bulgaria so far, which leads us to believe that such missing elements have only local significance and do not hinder our correlation. In view of current knowledge, it is impossible to assess satisfactorily the validity of the generic (subgeneric) names for Bulgarian Bathonian ammonites. Therefore, this account comprises generic names taken from past Bulgarian literature, but also previously used subgenera raised to the rank of genera alongside reclassified species now assigned to other genera, in accordance with new data.

The lower boundary of the Bathonian in Bulgaria is drawn at the appearance in numbers of the ammonite genera Lobosphinctes and Planisphinctes, followed up-section by Siemiradzkia, as well as at the advent of the genera Morphoceras and Ebrayiceras. It roughly coincides with the increased diversification of the genera Oxycerites and Oecotraustes (O. genicularis Waagen, the type-species of the latter taxonomic group, is a microconch of Oppelia; cf. FernándezLópez, 1985, p. 229). The decline of the parkinsoniids, such as Parkinsonia and Gonolkites, has been recorded near the base of the stage. The upper boundary of the Bathonian is drawn below the mass incoming of Macrocephalites (sensu lato). Regardless of their low stratigraphical value, it should be noted that the ammonites of the genus Lissoceras are fairly common. It should be also noted that the Phylloceratina appear in increased numbers, in contrast to the rocks from older Jurassic stages, where they are extremely rare. The threefold subdivision of the Bathonian in Bulgaria, first applied by Sapunov and Stephanov (1964), is followed herein (Table 1), and our views on the extent of the Bathonian substages are supported by details for each of the constituent ammonite zones.

\section{LOWER BATHONIAN AMMONITE ZONES}

The lower Bathonian in Bulgaria corresponds to the combined stratigraphical distribution of the following ammonite genera: Lobosphinctes, Planisphinctes, Siemiradzkia, Morphoceras, Ebrayiceras, Cadomites and Polyplectites. The latter two genera continued ranging from the upper Bajocian but evolved into new species. The lower Bathonian also includes the main occurrence of the genus Oecotraustes, as well as of two groups of the genus Oxycerites: $O$. gr. aspidoides (Oppel) and $O$. gr. fallax (Guéranger). Paroecotraustes probably appears around the middle of the substage. The first Bullatimorphites appears near the top. Three ammonite zones have been distinguished: Gonolkites convergens, Morphoceras macrescens and Siemiradzkia repljanensis (Table 1). The former two zones cover the extent of the Convergens and the Multiforme subzones, respectively, of the Zigzag Zone sensu Sapunov and Stephanov (1964), whereas the $S$. repljanensis Zone substitutes the Fallax Subzone of the Zigzag Zone (Stephanov, 1972). Since the genus Zigzagiceras has never been found in Bulgaria, the Zigzag Zone was abandoned. The absence of a stratigraphical link between the associations of the former subzones motivated us to promote these subzones to the rank of zones.

\section{Gonolkites convergens Zone}

This zone corresponds to the Convergens Subzone of the Zigzag Zone as used by Stephanov (1972). We retain the name, although we opine that this taxon is unsuitable for index species, because it has never been recorded and the genus Gonolkites is uncommon in Bulgaria. We could offer as local index for this association some of the known species of the genera Lobosphinctes and Planisphinctes, since these ammonites are widespread at the very base of the Bathonian. The genus Lobosphinctes, as interpreted herein, includes ammonites previously assigned to Procerites (Stephanov, 1961), whereas Planisphinctes includes species formerly classified as a subgenus of the genus Siemiradzkia (Stephanov, 1972). The ranges of these genera have not been defined properly in more expanded successions to date. No alternatives from the co-occurring ammonites of the association are available, as the rest of our material consists of ancillary elements in the form of rare Cadomites and Polyplectites, and scarce Oxycerites and Oecotraustes, none of which is yet sufficiently well known to be a reliable guide species. We consider that the G. convergens Zone in Bulgaria approximates the Morphoceras parvum Subzone of the Zigzagiceras zigzag Zone proposed in the Submediterranean scheme of Mangold and Rioult (1997), as the record from this association includes enough characteristic species that often occur in abundance. The revision of the type-section of the Bov Formation, including some newly excavated sections in the type-area of this formation, has recently extended our knowledge of the Bathonian deposits to the Bulgarian/Serbian border region in West Bulgaria (GubeshKomshtitsa villages area) and in East Serbia (Senokos Village area), and allowed the reconstruction of a biostratigraphically reliable sequence. Hence, the association of the $G$. convergens Zone was seen in a 
few decimetre-thick fossiliferous beds, with numerous Lobosphinctes tmetolobus (Buckman), L. subprocerus (Buckman), Planisphinctes incognitus Stephanov, $P$. planilobus (Buckman) and P. donovani (Stephanov), associated with less common Cadomites, Polyplectites and Gonolkites. In addition, from other known locali- ties in Bulgaria, this zone also includes scattered ammonites of the genus Parkinsonia. Thus, the Bulgarian G. convergens Zone comprises a reasonable composition in comparison to the GSSP for the base of the Bathonian Stage (see Pavia et al., 2008; FernándezLópez et al., 2009).

Table 1

Correlation between the Bulgarian Bathonian ammonite zones and the standard zones and subzones of the NW European and Submediterranean provinces (after Mangold and Rioult, 1997)

\begin{tabular}{|c|c|c|c|c|c|c|c|}
\hline \multirow{2}{*}{ 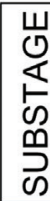 } & \multicolumn{2}{|c|}{ Submediterranean Province } & \multicolumn{2}{|c|}{ Bulgaria } & \multicolumn{2}{|c|}{ NW European Province } & \multirow{2}{*}{ 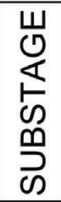 } \\
\hline & Zone & Subzone & Ammonites* & Zone & Subzone & Zone & \\
\hline \multirow{4}{*}{ 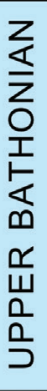 } & \multirow{2}{*}{$\begin{array}{l}\text { Clydoniceras } \\
\text { discus }\end{array}$} & $\begin{array}{l}\text { Clydoniceras } \\
\text { discus }\end{array}$ & & \multirow{2}{*}{$\begin{array}{l}\text { Clydoniceras } \\
\text { discus }\end{array}$} & \begin{tabular}{|c|}
$\begin{array}{c}\text { Clydoniceras } \\
\text { discus }\end{array}$ \\
\end{tabular} & \multirow{2}{*}{$\begin{array}{l}\text { Clydoniceras } \\
\text { discus }\end{array}$} & \\
\hline & & $\begin{array}{c}\text { Clydoniceras hol- } \\
\text { landi/H. }(P .) \text { anguli- } \\
\text { costatum }\end{array}$ & & & $\begin{array}{c}\text { Clydoniceras } \\
\text { hollandi }\end{array}$ & & $\frac{z}{z}$ \\
\hline & \multirow{2}{*}{$\begin{array}{l}\text { Hecticoceras } \\
\text { (Prohecticoceras) } \\
\text { retrocostatum }\end{array}$} & $\begin{array}{l}\text { B. (K.) hannovera- } \\
\text { nus/(E. histricoides) }\end{array}$ & & \multirow{2}{*}{$\begin{array}{l}\text { Oxycerites } \\
\text { oppeli }\end{array}$} & $\begin{array}{c}\text { B. (K.) } \\
\text { hannoveranus }\end{array}$ & \multirow{2}{*}{$\begin{array}{c}\text { Oxycerites } \\
\text { oppeli/(orbis) }\end{array}$} & 卢 \\
\hline & & $\begin{array}{c}\text { H. (P.) blanazense/ } \\
\text { (H. julii) }\end{array}$ & & & $\begin{array}{c}\text { H. }(P .) \\
\text { blanazense }\end{array}$ & & \\
\hline \multirow{6}{*}{ 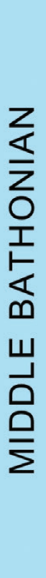 } & \multirow{2}{*}{$\begin{array}{c}\text { Cadomites } \\
\text { bremeri }\end{array}$} & $\begin{array}{l}\text { Wagnericeras } \\
\text { fortecostatum }\end{array}$ & & \multirow{2}{*}{$\begin{array}{l}\text { Procerites } \\
\text { hodsoni }\end{array}$} & \multirow{2}{*}{\multicolumn{2}{|c|}{ Procerites hodsoni }} & \\
\hline & & $\begin{array}{l}\text { Bullatimorphites } \\
\text { bullatimorphus }\end{array}$ & & & & & \\
\hline & \multicolumn{2}{|c|}{ Morrisiceras morrisi } & & $\begin{array}{c}\text { Morrisiceras } \\
\text { morrisi }\end{array}$ & \multicolumn{2}{|c|}{ Morrisiceras morrisi } & 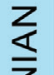 \\
\hline & \multicolumn{2}{|c|}{ Tulites subcontractus } & & $\begin{array}{l}\text { Tulites } \\
\text { subcontractus }\end{array}$ & \multicolumn{2}{|c|}{ Tulites subcontractus } & \\
\hline & \multirow{2}{*}{$\begin{array}{l}\text { Procerites } \\
\text { progracilis }\end{array}$} & $\begin{array}{l}\text { Procerites } \\
\text { progracilis }\end{array}$ & & \multirow{2}{*}{$\begin{array}{l}\text { Procerites } \\
\text { progracilis }\end{array}$} & \multirow{2}{*}{\multicolumn{2}{|c|}{ Procerites progracilis }} & \\
\hline & & $\begin{array}{c}\text { Cadomites } \\
\text { orbignyi }\end{array}$ & & & & & $\sum$ \\
\hline \multirow{4}{*}{ 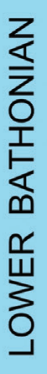 } & \multirow{2}{*}{$\begin{array}{l}\text { Procerites (Siemi- } \\
\text { radzkia) aurigerus }\end{array}$} & $\begin{array}{l}\text { Asphinctes } \\
\text { tenuiplicatus }\end{array}$ & & \multirow{2}{*}{$\begin{array}{l}\text { Siemiradzkia } \\
\text { repljanensis }\end{array}$} & \multicolumn{2}{|c|}{ Asphinctes tenuiplicatus } & $\stackrel{2}{s}$ \\
\hline & & $\begin{array}{l}\text { Asphinctes } \\
\text { recinctus }\end{array}$ & & & $\begin{array}{l}\text { Oxycerites } \\
\text { yeoviliensis }\end{array}$ & \multirow{3}{*}{$\begin{array}{c}\text { Zigzagiceras } \\
\text { zigzag }\end{array}$} & I \\
\hline & \multirow{2}{*}{$\begin{array}{l}\text { Zigzagiceras } \\
\text { zigzag }\end{array}$} & $\begin{array}{l}\text { Morphoceras } \\
\text { macrescens }\end{array}$ & & $\begin{array}{l}\text { Morphoceras } \\
\text { macrescens }\end{array}$ & $\begin{array}{l}\text { Morphoceras } \\
\text { macrescens }\end{array}$ & & $\frac{\alpha}{\Psi}$ \\
\hline & & $\begin{array}{l}\text { Morphoceras } \\
\text { parvum }\end{array}$ & & $\begin{array}{l}\text { Gonolkites } \\
\text { convergens }\end{array}$ & $\begin{array}{l}\text { Gonolkites } \\
\text { convergens }\end{array}$ & & \\
\hline
\end{tabular}

*Diagnostic and ancillary species: a) Lobosphinctes tmetolobus (Buckman); b) Planisphinctes donovani (Stephanov); c) Morphoceras macrescens (Buckman); d) Siemiradzkia procera (von Seebach); e) Siemiradzkia repljanensis Stephanov; f) Oxycerites gr. fallax (Guéranger); g) Siemiradzkia britanica Stephanov; h) Siemiradzkia irregularis Stephanov; i) Cadomites orbignyi (de Grossouvre); j) Siemiradzkia strungensis Stephanov; k) Siemiradzkia pseudorjazanensis (Lissajous); l) Siemiradzkia matisconensis (Lissajous); m) Rugiferites rugifer (Buckman); n) Siemiradzkia davitashvilii Stephanov; o) Paroecotraustes prevalensis (Stephanov); $p$ ) Procerites gr. wattonensis Arkell; q) Procerites magnificus Arkell; r) Wagnericeras lissajousi (Beznosov); s) Prevalia pseudoperspicua (Stephanov); $t$ ) Homoeoplanulites mouterdei Mangold, Martin \& Prieur; $u$ ) Traxites haemussensis (Stephanov); v) Choffatia vicenti Mangold; w) Oxycerites oppeli Elmi; x) Clydoniceras discus (J. de C. Sowerby); y) Choffatia richei Mangold; z) Choffatia arisphinctoides (Arkell). 


\section{Morphoceras macrescens Zone}

The zone includes the stratigraphical distribution of the ammonite genera Morphoceras and Ebrayiceras. As stated above, it corresponds to the Multiforme Subzone of the Zigzag Zone as established by Stephanov (1972), who used Morphoceras multiforme Arkell as a guide fossil, assuming that it is more common in Bulgaria than Morphoceras macrescens (S. Buckman). However, numerous specimens of $M$. macrescens have been recorded during the last years, showing that this species is common enough and its presence is a sufficient indication to denote the zone in which it occurs. The stratigraphical relationship between the $\mathrm{mul}$ tiforme and macrescens faunas is unclear in Bulgaria, but there are indications that Morphoceras emerges later than the earliest record of the genus documented elsewhere (e.g., Pavia et al., 2008; Fernández-López et al., 2009). The $M$. macrescens Zone is typified by the index-species and $M$. multiforme, as well as by much less-common Ebrayiceras pseudoanceps (Ebray) and E. gr. sulcatum (Zieten). Frequent Oxycerites gr. posterus (Wetzel), O. yeoviliensis Rollier and Polyplectites linguiferus (d'Orbigny) are also associated with this zone. Some of the ammonites assigned by Stephanov (1966) to Oecotraustes nodifer Buckman and $O$. costiger Buckman are probably related to this association, but their exact occurrence is not clear, due to imperfect preservation in condensed beds. The zonal association provides the earliest record of the genera Siemiradzkia and Paroecotraustes, including Siemiradzkia gr. procera (von Seebach) and Paroecotraustes spp. Regardless of the paucity of the assemblage list, we suggest that the $M$. macrescens Zone in Bulgaria is equivalent to the $M$. macrescens Subzone of the $Z$. zigzag Zone in the Submediterranean zonal scale of Mangold and Rioult (1997).

\section{Siemiradzkia repljanensis Zone}

This zone replaces the Fallax Zone from the earlier scheme of Sapunov and Stephanov (1964) and the Fallax Subzone of the Zigzag Zone of Stephanov (1972). We prefer this index to Oxycerites fallax (Guéranger). The latter is not a suitable index as very similar Oxycerites species occur in the lower Bathonian and their exact stratigraphic position is not precisely known. Therefore, it would be better to use the local index-species Siemiradzkia repljanensis Stephanov, since the presence of the possibly coeval $S$. aurigera (Oppel), which is widely used abroad, is doubtful in Bulgaria (see Stephanov, 1972, pp. 52, 53). We assume a wider development of the $S$. repljanensis Zone than that adopted by previous authors in Bulgaria. It was thought that the zonal association is incomplete due to the lack of ammonites related to the upper part of the zone. However, we have recently discovered several fragments of "Asphinctites" spp., "Procerites" gr. imitator (Buckman) and Bullatimorphites gr. latecentratus (Quenstedt) that give us rea- son to conclude that the S. repljanensis Zone includes at least some of the missing members of this association. The main content of the zone corresponds to the indexspecies itself, as well as to Siemiradzkia faunas, such as $S$. irregularis Stephanov, S. procera (von Seebach) and $S$. britanica Stephanov. These species were carefully studied by Stephanov (1972) but all were from condensed deposits. Our confidence to classify them biostratigraphically now comes from the new sequences of the Bov Formation, in which we found good matches. Conditionally, we assign to this zone Oxycerites fallax and $O$. seebachi. In view of these considerations, it is believable that the $S$. repljanensis Zone is an equivalent of the Submediterranean Procerites (Siemiradzkia) aurigerus Zone (Mangold and Rioult, 1997).

\section{MIDDLE BATHONIAN AMMONITE ZONES}

The middle Bathonian in Bulgaria corresponds to the combined occurrence of species from the ammonite genera Procerites, Siemiradzkia and Cadomites. The Bullatimorphites, Tulites, and Oxycerites gr. oxus (Buckman) also occur, but sporadically. Morrisiceras are virtually absent. We propose three ammonite zones to be in use: Procerites progracilis, Tulites subcontractus and Morrisiceras morrisi (Table 1). The zones retain the names as used by Sapunov and Stephanov (1964). However, these labels stay behind ammonite assemblages that remain poorly defined. In practice, it is often not possible to distinguish reliable material. Neither the indices nor the ammonite zones are easily discernible, and more data are needed to refine them.

\section{Procerites progracilis Zone}

This zone has been overlooked within the scarce Procerites gr. progracilis specimens that were used as the basis for its introduction in Bulgaria (Sapunov and Stephanov, 1964). In the following works of Stephanov $(1966,1972)$, this situation persisted, as these were Stephanov's last publications, which appeared after his death. It has recently been confirmed that the beds from this level often yield Procerites faunas, but they display such an irregular occurrence and incomplete preservation that no certain identification is possible. It has also been found that this level contains Cadomites gr. orbignyi (de Grossouvre) and Polyplectites spp., which are better preserved than Procerites. However, both Cadomites and Polyplectites are not good guide fossils due to the considerable homeomorphism between different species (see Page, 1996). Scarce Oecotraustes occur in this level, but they are not good guide fossils, either. Yet with no comparable faunas, the upper parts of the beds attributable to the $P$. progracilis Zone provided common specimens of Siemiradzkia. A careful study of descriptions given by J. Stephanov led us to conclude that these ammonites match the description of Siemiradzkia strungensis 
(Stephanov, 1972, pp. 55-56), although he suggested a higher stratigraphical distribution of this species. We believe that its original position is within this zone, and this taxon likely has older range than reported in the original publication. It is probable that the top of the $P$. progracilis Zone equates to the first appearance of large Procerites faunas, namely Procerites mirabilis (Arkell). Although the association of this zone in Bulgaria is quite poor in composition, we suggest it as approximate equivalent of the $P$. progracilis Zone in the scheme of Mangold and Rioult (1997).

\section{Tulites subcontractus and Morrisiceras morrisi zones}

These zones were both introduced without adequate record and clear definitions. Stephanov (1963) and Sapunov and Stephanov (1964) concisely applied the Subcontractus Zone. Likewise, Stephanov (1966, 1972) used it later, but he inserted the Morrisi Zone at the top of the middle Bathonian, probably on account of the upper wider part of the Subcontractus Zone. Therefore, we face the problem of what to do with these zones. We are confident that no authentic Morrisiceras record exists in Bulgaria. The Tulites faunas, whose distribution is supposed to be present in these zones, occur inconsistently. Hence, the need for new indices is essential. It is the genus Siemiradzkia that presents the only valuable element of these ammonite associations. We are presently unable to provide a solution, and therefore the T. subcontractus and the M. morrisi zones remain in use.

The Tulites subcontractus Zone, as now recognized, includes several Tulites spp., single Rugiferites polypleurus (Buckman) and R. rugifer (Buckman), a few Bullatimorphites spp., as well as possibly the latest representatives of Oecotraustes nodifer Buckman. Also, it comprises Paroecotraustes gr. splendens Arkell, some poorly preserved Oxycerites gr. oxus (Buckman), as well as Siemiradzkia, in which we recognized common specimens of S. davitashvilii Stephanov. This reduced faunal list reflects some elements listed from the T. subcontractus Zone by Mangold and Rioult (1997, pp. 58, 59).

The ammonites attributed to the Morrisiceras morrisi Zone have not been confirmed by the occurrence of true Morrisiceras in Bulgaria to date. It appears that the Morrisi Zone sensu Stephanov $(1966,1972)$ is quite capacious and probably corresponds to the combined extent of the Morrisiceras morrisi and the Cadomites bremeri zones, which are in the Submediterranean scheme (Mangold and Rioult, 1997). The $M$. morrisi Zone, as now used, has a narrower extent than previously thought and, on account of the upper part of the earlier Morrisi Zone and the older Retrocostatum Zone sensu Stephanov (1966, 1972), we propose the Procerites hodsoni Zone (see below). Our data have not yet been recorded widely in a normal sequence, but progress is being made. The main components of the present $M$. morrisi Zone are two groups of ammonites of the genera Siemiradzkia and Paroecotraustes: Siemiradzkia matisconensis (Lissajous) (including S. triballa and S. galla taken from Stephanov, 1972, that do not appear to be a distinct species, but merely morphological variants), S. pseudorjazanensis (Lissajous), Paroecotraustes ziegleri (Stephanov), P. splendens (Arkell), P. formosus (Arkell) and P. glojanensis (Stephanov). Together, these faunas are the only evidence based on which an approximate correlation between the Bulgarian M. morrisi Zone and the coeval Submediterranean ammonite zone in the scheme of Mangold and Rioult (1997) can be drawn.

\section{UPPER BATHONIAN AMMONITE ZONES}

Following the scarcely fossiliferous middle Bathonian strata, the rocks of the upper Bathonian yielded numerous and diverse ammonites from both older Bulgarian collections and the newly obtained specimens. However, the middle/upper Bathonian boundary remains arbitrary, and it is impossible to be more precisely drawn for the time being. The upper Bathonian corresponds to the occurrence of the genera Procerites, Siemiradzkia, Prevalia, Wagnericeras, Oxycerites and Clydoniceras, although the latter genus occurs rarely. Paroecotraustes persisted to and became extinct at the top of the substage. The genus Thraxites emerged near the base. The first pseudoperisphictids appeared and diversified throughout the substage, and common $\mathrm{Ho}$ moeoplanulites and less frequent Choffatia are also recorded. They range upwards into the lower Callovian but occur as different species. Rare Bullatimorphites and Hemigarantia were also evidenced. The upper Bathonian is subdivided into the Procerites hodsoni, Oxycerites oppeli and Clydoniceras discus zones (Table 1). The former two zones correspond to the older Aspidoides Zone (Sapunov and Stephanov, 1964) and its later divisions, the "Retrocostatum" Zone and the "Aspidoides Zone" (Stephanov, 1966), whereas the topmost zone conforms to the Discus Zone of Sapunov and Stephanov (1964) and Stephanov (1972). With respect to the older Discus Zone, the occurrence of the zonal index was virtually the only criterion to identify the zone in previous times. The only known record of Clydoniceras discus (Sowerby) is based on a few ammonites from two localities in Bulgaria.

\section{Procerites hodsoni Zone}

The older name, Prohecticoceras retrocostatum (de Grossouvre), has always been tentatively used as an index (see Stephanov, 1966), since the true Prohecticoceras are rare in Bulgaria. The name "Aspidoides" is also inappropriate. As stated by Dietl (1982), the type locality of Oxycerites aspidoides (Oppel) lies stratigraphically in much lower horizon than previously thought (i.e., the upper Bajocian/lower Batho- 
nian boundary interval), and hence this species cannot any longer be used as index for the upper Bathonian. In support of this view, Mangold and Rioult (1997) stated that $O$. aspidoides is present in the lower $\mathrm{Ba}-$ thonian, regardless of whether it would be considered a separate species or interpreted as a morphological variant of another species of the genus Oxycerites. Accordingly, the upper Bathonian Oxycerites faunas that are similar, but clearly stratigraphically separated from $O$. aspidoides, must be distinguished and placed in another species. Elmi (1967) erected Oxycerites oppeli to address this issue. In agreement with that view, the "Aspidoides Zone" has recently been disused in Bulgaria (Metodiev et al., 2013).

The main elements of the Procerites hodsoni Zone are the abundant Procerites species [e.g., Procerites gr. quercinus (Terquem \& Jourdy), P. gr. wattonensis Arkell, P. hodsoni Arkell and P. magnificus Arkell]. Significant components of this association are the species of the genus Prevalia: P. pseudoperspicua (Stephanov), P. subfluctucosa (Lissajous), P. bassae (Stephanov), P. subcongener (Lissajous), P. prevalensis (Stephanov) and $P$. thressa (Stephanov). Some of these species may range higher but do not reach the $C$. discus Zone. The P. hodsoni Zone also yielded common Siemiradzkia berthae (Lissajous), Paroecotraustes maubeugei (Stephanov), P. splendens (Arkell) and P. ziegleri (Stephanov). Some of them came from below and continued ranging up-section. The zonal association also includes common Wagnericeras species (see Metodiev, 2015). The pseudoperisphinctids recorded from this zone are similar to those from the French Jura Mts (Mangold, 1970 Mangold et al., 2012). We obtained some Homoeoplanulites mouterdei Mangold, Martin \& Prieur, H. bugesiacus (Dominjon) and Choffatia vicenti Mangold. The association also includes scarce Bullatimorphites stephanovi Galácz, Traxites haemussensis (Stephanov) and a single Hemigarantia julii (d'Orbigny). The recorded species have significance for improving the definition of the Bulgarian P. hodsoni Zone, but not enough specimens have yet become available to characterize its range and variability. The extent of this zone in Bulgaria, even as it stands, coincides with the full extent of the Submediterranean Cadomites bremeri Zone plus the base of the Hecticoceras (Prohecticoceras) retrocostatum Zone. It is at the same time a local equivalent of the NW European P. hodsoni Zone (Mangold and Rioult, 1997). Thus, the middle/upper Bathonian boundary is moved lower than it was previously drawn in Bulgaria, so that it matches the one defined in Northwest Europe.

\section{Oxycerites oppeli Zone}

This zone has only recently been introduced in Bulgaria (Metodiev et al., 2013). It contains good examples of the index-species, as well as of Oxycerites subinflexus (de Grossouvre) and Paroecotraustes waageni (Stephanov). We supplement the zonal association with examples of Homoeoplanulites couxi (Dominjon), H. mangoldi (Dominjon), Choffatia praecursor Mangold and Choffatia richei Mangold. It appears that the faunal content of the $O$. oppeli Zone is sufficiently comparable to that from the NW European Oxycerites oppeli/(orbis) Zone and resembles to a lesser extent the Submediterranean $H$. (P.) retrocostatum Zone (Mangold and Rioult, 1997). So far, the known Bulgarian ammonite fields do not indicate the existence of characteristic faunas of Submediterranean dispersal, such as Bomburites-Kheraiceras, Epistrenoceras and Parapatoceras.

\section{Clydoniceras discus Zone}

The Clydoniceras discus Zone, used in earlier works of Stephanov, relies only on the occurrence of the index. Two subzones, "Hollandi" and "Discus", were used in his last work (Stephanov, 1972). However, we did not find any original supporting evidence. Recent efforts to advance our understanding of this zone have made little improvement in the identification of two commonly encountered upper Bathonian groups of ammonites assigned to Choffatia: C. arisphinctoides (Arkell) and C. arkelli Mangold. Some Homoeoplanulites also occur but have not been studied yet. Attempts must be made to gather more material in order to conclude if this zone really is an equivalent of the $C$. discus Zone as used in Europe (Mangold and Rioult, 1997).

\section{CONCLUSIONS}

As demonstrated in this account, a composite Submediterranean-Northwest European zonation seems to be applicable to the successions of Bathonian ammonite faunas in Bulgaria. And here arises the question whether it is appropriate to restrict one or another group of Bathonian ammonites to NW European or Submediterranean preference. It is apparent that the roles of the genera and species typifying the zonal associations are inconsistent. Also, it is clear that certain genera, especially Lobosphinctes, Planisphinctes, Siemiradzkia, Prevalia, Choffatia and Homoeoplanulites, are the taxa that have the greatest potential for building more correlative ammonite zonal set for the Bathonian in Bulgaria.

\section{Acknowledgements}

The authors are grateful to Prof. Sixto Fernández-López (Universidad Complutense, Madrid) for useful suggestions and comments. We thank Mr Robert Chandler (Natural History Museum, London) and Dr Georgi Granchovski (Geological Institute, Sofia) for their help with improving the manuscript. Special thanks are due to Prof. Dragoman Rabrenović (Serbian Geological Survey, Belgrade), who generously provided access to his Bathonian ammonites from Senokos (Serbia). 


\section{REFERENCES}

Cope, J.C.W, Duff, K.L., Parsons, C.F., Torrens, H.S., Wimbledon, W.A., Wright, J.K. 1980. A correlation of Jurassic rocks in the British Isles, Part Two: Middle and Upper Jurassic. Geological Society London, Special Report 15, $1-109$.

Dietl, G. 1982. Das wirkliche Fundniveau von Ammonites aspidoides Oppel (Ammonoidea, Mittl. Jura) am locus typicus. Stuttgarter Beiträge zur Naturkunde, Serie B 87, $21 \mathrm{pp}$.

Elmi, S. 1967. Le Lias supérieur et le Jurassique moyen de l'Ardèche. Documents des Laboratoires de Géologie, Lyon 19 (2), 257-507.

Fernández-López, S.R. 1985. El Bajocience en la Cordillera Ibérica. $\mathrm{PhD}$ thesis, Universidad Complutense de Madrid, Madrid, $850 \mathrm{pp}$.

Fernández-López, S.R., Pavia, G., Erba, E, Guiomar, M., Henriques, M.H., Lanza, R., Mangold, C., Morton, N., Olivero, D., Tiraboschi, D. 2009. The Global Boundary Stratotype Section and Point (GSSP) for base of the Bathonian Stage (Middle Jurassic), Ravin du Bès Section, SE France. Episodes 32 (4), 222-248.

Géczy, B., Galácz, A. 1998. Bathonian ammonites from the classic Middle Jurassic locality of Villány, South Hungary. Revue de Paléobiologie 17 (2), 479-511.

Mangold, C. 1970. Les Perisphinctidae (Ammonitina) du Jura méridional au Bathonien et au Callovien. Documents des Laboratoires de Géologie, Lyon 41 (2), 246 pp.

Mangold, C., Poirot, E., Lathullière, B., Le Roux, J. 1994. Biochronologie du Bajocien supérieur et du Bathonien de Lorraine (France). Géobios 17, 343-349.

Mangold, C., Rioult, M. 1997. Bathonien. In: Groupe français d'étude du Jurassique, Cariou, E., Hantzpergue, P. (Eds), Biostratigraphie ouest-européen et méditerranéen: zonations parallèles et distribution des invertébrés et microfossiles. Bulletin du Centre des recherches Elf Exploration Production 17, 55-62.

Mangold, C., Martin, A., Prieur, A. 2012. Les Périsphinctidés du Bathonien moyen et supérieur du Mâconnais (Saône-etLoire, France). Documents des Laboratoires de Géologie, Lyon 169, 155 pp.

Metodiev L., Koleva-Rekalova, E., Dochev, D., Sirakov, V. 2013. New data on the age of the Polaten Formation in Central Balkan Mountains. Bulgarian Geological Society, National Conference with international participation "Geosciences 2013", Abstracts, 73-74.
Metodiev L. 2015. New examples of the genus Wagnericeras from the Bathonian in Bulgaria. Bulgarian Geological Society, National Conference with international participation "Geosciences 2015", Abstracts, 113-114.

Page, K.N. 1996. Observations on the succession of stratigraphically useful ammonite faunas in the Bathonian (Middle Jurassic) of southwest England, and their correlation with a Sub-Mediterranean 'Standard Zonation'. Proceedings of the Ussher Society 9, 045-053.

Pavia, G., Fernández-López, S.R., Mangold, C. 2008. Ammonoid succession at the Bajocian-Bathonian transition in the Bas Auran Area, Digne District, South-east France. Rivista Italiana di Paleontologia e Stratigrafia 114 (2), 287-311.

Sacharieva-Kowatcheva, K. 1956. Faunistische und stratigraphische Untersuchung des Doggers im Westlichen Balkan. Annuaire de l'Université de Sofia, Faculté de Biologie, Géologie et Géographie 49, 217-346 (in Bulgarian, with German abstract).

Sandoval, J. 1983. Bioestratigrafia y paleontología (Stephanocerataceae y Perisphinctaceae) del Bajocience y Bathonense en las Cordilleras Béticas. $\mathrm{PhD}$ thesis, Universidad de Granada, Granada, 613 pp.

Sapunov, I., Stephanov, J. 1964. The stages, substages, ammonite zones and subzones of the Lower and Middle Jurassic in the Western and Central Balkan Range (Bulgaria). In: Maubeuge, P.L. (Ed.), Colloque du Jurassique, Luxembourg 1962, Volume Comptes Rendus et Mémoires, Imprimerie St-Paul, S.A., Luxembourg, 705-718.

Schlegelmilch, R. 1985. Die Ammoniten des süddeutschen Doggers. Gustaf Fischer, Stuttgart, New York, 279 pp.

Stephanov, J. 1961. The Bathonian in the section of the Belogradchik-gara Oreshets road (North-west Bulgaria). Bulletin of the Geological Institute, Series Palaeontology 9, 337-355 (in Bulgarian, with English abstract).

Stephanov, J.1963. Bathonian ammonites of the Superfamily Stephanocerataceae in Bulgaria. Travaux sur la géologie de Bulgarie, Série Paléontologie 5, 167-197 (in Bulgarian, with English abstract).

Stephanov, J. 1966. The Middle Jurassic ammonite genus Oecotraustes Waagen. Travaux sur la géologie de Bulgarie, Série Paléontologie 8, 29-69.

Stephanov, J. 1972. Monograph on the Bathonian ammonite genus Siemiradzkia Hyatt, 1900 (nomenclature, taxonomy and phylogeny). Bulletin of the Geological Institute, Series Palaeontology 21, 5-82. 